\title{
Electrical Measurements in the Selection of Bolt Materials for Service Underground
}

\author{
W. J. Schwerdtfeger
}

\begin{abstract}
Electrical measurements made in the laboratory are useful in generally predicting the relative behavior of bolt materials underground as pertaining to the corrosive effect of the soil. Some arbitrarily chosen low-alloy ferrous materials are shown to be superior to plain cast iron or steel commonly used for the fabrication of bolts. The effect of exposure on the potentials of cast iron and galvanized iron as components of galvanic couples is described
\end{abstract}

\section{Introduction}

Although failures of plain ferrous bolts underground are confined chiefly to severely corrosive environments, the costs attributed to shutdowns and repairs are high. Figure 1 shows bolts removed from couples exposed to 14 underground environments, including cinders (site 67), and illustrates the effect of 13 years of exposure at the National Bureau of Standards test sites. The 13 soils range from moderate to severe corrosivity, except for sites 53 and 55, which are slightly corrosive.

In very corrosive soils, bolt failures may occur before severe corrosive effects take place on the structures to which the bolts are coupled. Primarily responsible for such failures, aside from normally accelerated corrosion due to stress and edge effects, are probably the effects due to galvanic action between the bolts and the structures.

The solution to the problem then seemingly lies in the use of bolts fabricated from materials that are cathodic to the structure. Although ferrous bolts containing certain alloying constituents to make them cathodic to iron are available, their use might be discouraged because of greatly increased cost. Also, because of the potential difference between the coupled elements, it would appear that excessive localized attack might be expected to occur on the adjacent anodic structure. However, based on experimental work of other investigators, such fears are not always justified $[1,2,3] .^{1}$ The corrosion rates of materials, or their resistance to corrosion, can be measured by their polarizing characteristics, and it has been shown, for iron exposed to soil, that an increase in cathodic polarization is synonymous with a reduced rate of corrosion [4]. Direct current flowing to stainless-steel or nickel-copper alloy (7030 ) causes marked polarization because these materials are relatively free of potent local action. Thus, the coupling of relatively small areas of such materials to plain cast-iron or steel structures need not result in excessive galvanic corrosion to the structure. Also, whatever the galvanic eurrent, the weight loss on the adjacent anodic structure will not be increased by an amount equivalent to the magnitude of the current because the galvanic current will reduce local action on the affected anodic area $[4,5]$.

1 Figures in brackets indicate the literature references at the end of this paper.
In order to determine what electrical measurements might be of value in predicting the probable behavior of bolts for use underground, potential measurements were made on the components of galvanic couples, followed by exposure of the couples. to a very corrosive soil for 1 year in the laboratory. Potentials and currents were measured during the exposure period and weight losses obtained at the conclusion. Donoho and MacKenzie [6] found that the addition of 1 percent of copper to cast-iron bolts resulted in a marked reduction of corrosion on the bolts when coupled with plain cast iron. The work of these investigators also suggested the use of a small amount of nickel as a constituent of ferrous. bolts, the nickel being more soluble in iron than copper. As an extensive use of low-alloy bolts would not result in prohibitive installation costs to industry, such bolts were arbitrarily chosen for the main laboratory study, along with high-alloy castiron and nickel-copper alloy (70-30) bolts known to be cathodic to plain cast iron but which are relatively high in cost.

\section{Laboratory Procedure}

\subsection{Preliminary Potential Measurements}

Selecting bolts that are to be cathodic to a particular structure implies the necessity for a reproducible method of measuring potentials. It has been shown that potentials can be measured, with a reasonable degree of accuracy, by placing metallic specimens in puddled soil contained in a relatively airtight enclosure [7]. Under normal conditions of aeration underground, the open-circuit electromotive force between a bolt and the adjacent structure is not necessarily the same as the potential difference that exists in a relatively air-free environment. However, a reproducible method of measuring potentials would be useful in determining the effect of varying amounts of alloying constituents. As will be shown later, an inherent initial potential difference of only $10 \mathrm{mv}$ between the components of a couple has the effect of making the cathodic element considerably more cathodic with time.

The laboratory investigation to be described was. made with a very corrosive soil from Atlantic City, N. J., which has a $\mathrm{pH}$ of 4.4 and a resistivity of 140 ohm-cm. 

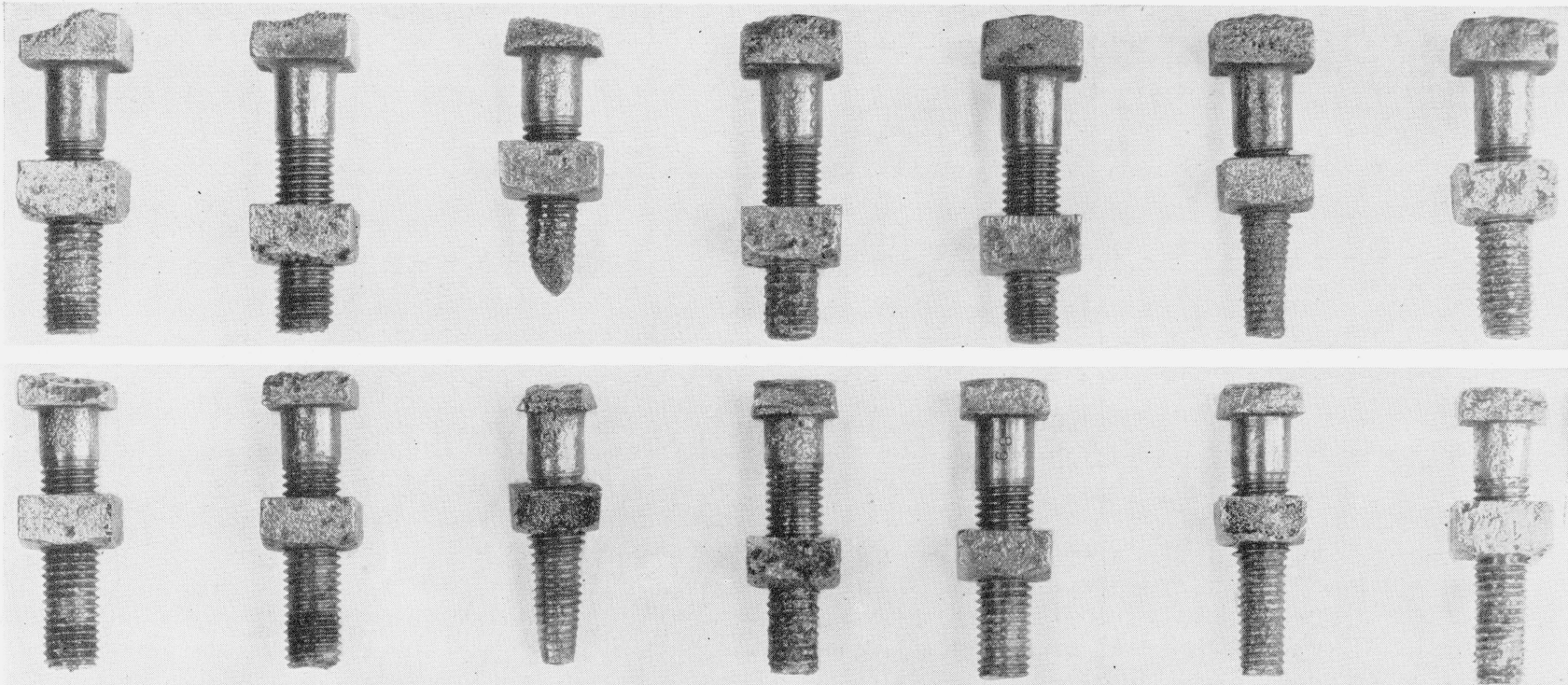

53

55

56

58

59

60

61.
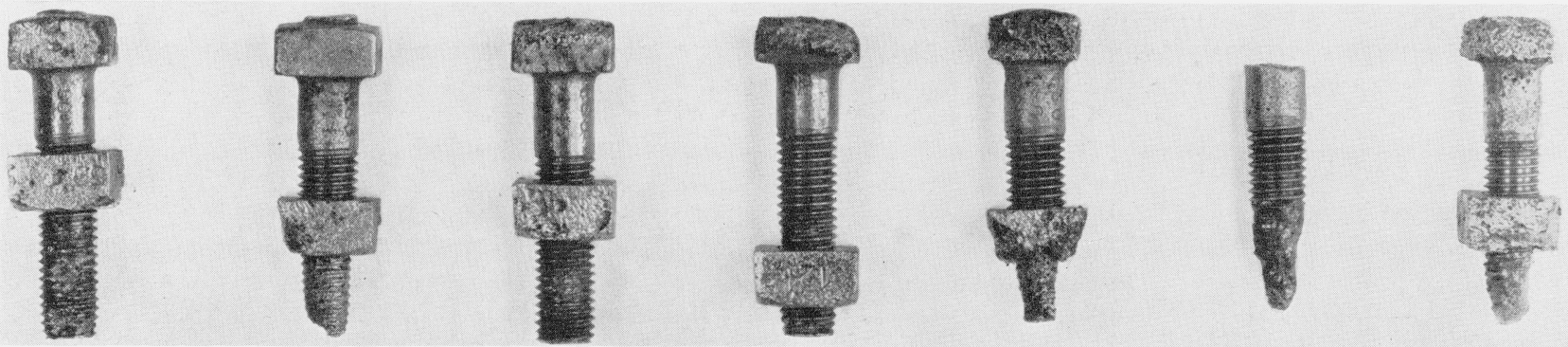

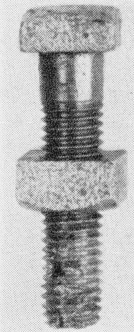

62

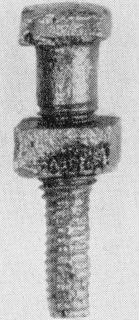

63

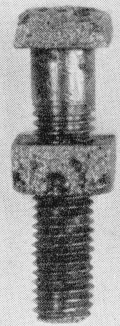

64

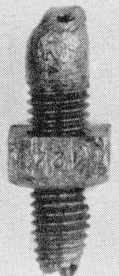

65

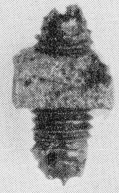

66

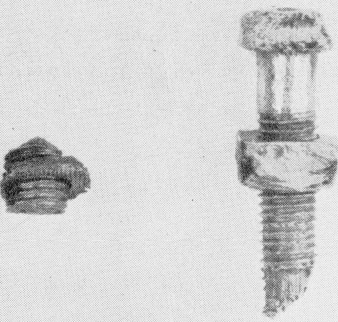

67

70

FIGURE 1. Bolts removed from couples after an underground period of 13 years at 14 NBS test sites.

A pair of bolts, cast iron (upper row) and steel (lower row), shown above the site numbers were components of a joint. Each pair of bolts ( 0.625 in. by 3 in.) joined two cast-iron plates $(0.5 \mathrm{in}$. by $3.5 \mathrm{in}$. by $12 \mathrm{in}$.) that overlapped by 1.5 in.

Potential measurements on the bolts were made prior to exposure of the couples to the soil. The bolts were first cleaned with carbon tetrachloride and then wire brushed. The electrical connection for the potential measurement was made through a single conductor No. 8 rubber-covered copper wire screwed into the head of each bolt, with molten asphalt being applied around the point of contact. Dry soil was broken up, ground, and passed through a No. 20 sieve. A sufficient quantity for a complete series of potential measurements was thoroughly mixed, watered, and mechanically worked over, with water being added gradually until the soil was saturated. Two bolts of the same size and composition were each covered with the saturated soil and then horizontally and laterally placed in a crystallizing dish (190 $\mathrm{mm}$ diam by $70 \mathrm{~mm}$ high), with the wires from the bolts protruding vertically over the top of the dish. More puddled soil was placed into the dish and so distributed as to fill all space to a depth within about $1 / 2$ in. from the top. Paraffin, barely molten, was then poured into the dish over the soil in sufficient quantity so as to flow around the wires and a No. 1 rubber stopper resting on top of the soil. An approximately 1/8-in. thickness of paraffin was found to form a fairly good air seal. 
As soon as the paraffin congealed, the rubber stopper was twisted so as to break the seal of adhering wax and left to rest lightly in position. The hole formed by the rubber stopper, about midway between the bolts and about 1 in. from the side of the dish, served to relieve any pressure developed inside the dish and also as a point of access to the soil for the reference electrode.

The potential measurements are given in table 1 , each value being the average for the two bolts. Except for high-alloy cast iron and the nickel-copper alloy, the average values might be considered as the steady-state potentials because of the slight deviations from the final values. The potentials of the high-alloy cast-iron and nickel-copper alloy bolts continued to get more anodic, presumably even after 45 days. The average variation of potential between similar bolts, except for high-alloy cast iron, was less than $2 \mathrm{mv}$. The potentials of the latter bolts differed on the average by $13 \mathrm{mv}$. Although the potentials of the high-alloy cast-iron and nickelcopper alloy bolts were still changing at the conclusion of the tests, there was no reason to doubt that the stable potentials would be cathodic to plain carbon steel and cast iron. Potentials of the castiron gland material, the other element of the couple, were found to be about the same as the values shown for plain carbon steel.

Earlier investigators have found that both nickel and copper additions will make iron more cathodic $[6,8]$. Copper, however, is less soluble in iron than nickel, only about 0.5 percent being dissolved at room temperature. Nickel, on the other hand, is very soluble in iron and, in addition, appears to increase the propensity for copper to dissolve in iron. Thus, while iron containing dissolved copper should be more cathodic than unalloyed iron, alloys of iron containing both copper and nickel should be even more cathodic. This effect of nickel is substantiated by the results given in table 1 , in which cast irons and steels containing copper and nickel are more cathodic than plain steel and cast iron containing 1 percent of copper.

TABle 1. Potentials of bolts in puddled soil

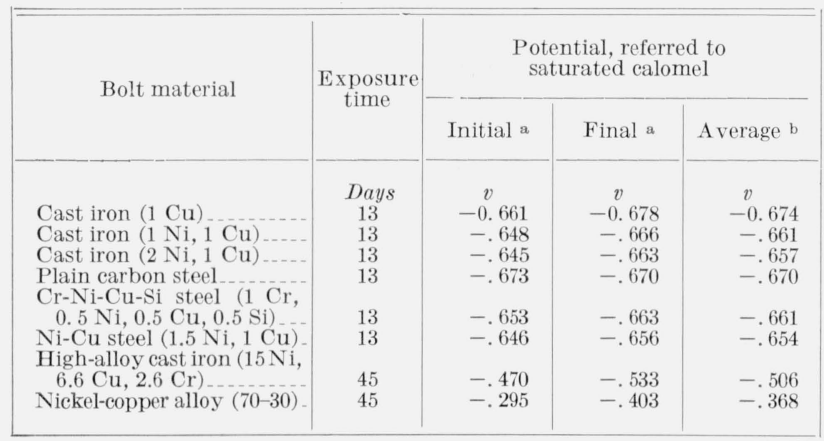

a Average of 2 bolts.

b Average for the exposure period (9 pairs of measurements in as many days for bolts exposed for 13 days and 19 pairs of measurements covering the 45-day exposure period).

\subsection{Coupling and Soil-Moistening Procedure}

Sections cut from 4-in. cast-iron pipe glands (components of mechanical joints) were bolted together to form test joints. Eight couples were assembled as shown in figure 2, using a different bolt material for each couple. In order to permit measurement of currents and potentials, the couple components were insulated by bushing the holes in the gland sections with Bakelite tubing and placing Bakelite washers under the heads and nuts of the bolts. For electrical connections, No. 8 single conductor rubber-covered copper wires were threaded and screwed into the gland sections and bolt heads, and molten asphalt was applied around the threads to reduce galvanic action. When electrical measurements were not being made, the bolts and gland sections were directly connected as shown in figure 2.

Prior to assembly, the bolts were degreased, wirebrushed, and weighed. The gland sections were also degreased, sand-blasted to remove paint, and weighed. Metal cans, 12 in. in diameter by 14 in. high, for holding the soil and couples were prepared by perforating the bottoms and covers with 1/8-in. holes about 1 in. apart and painting the metal surface, inside and outside, with two coats of bituminous paint.

About 4 in. of dry soil was placed in the can, and the couple was centrally positioned on the top of the

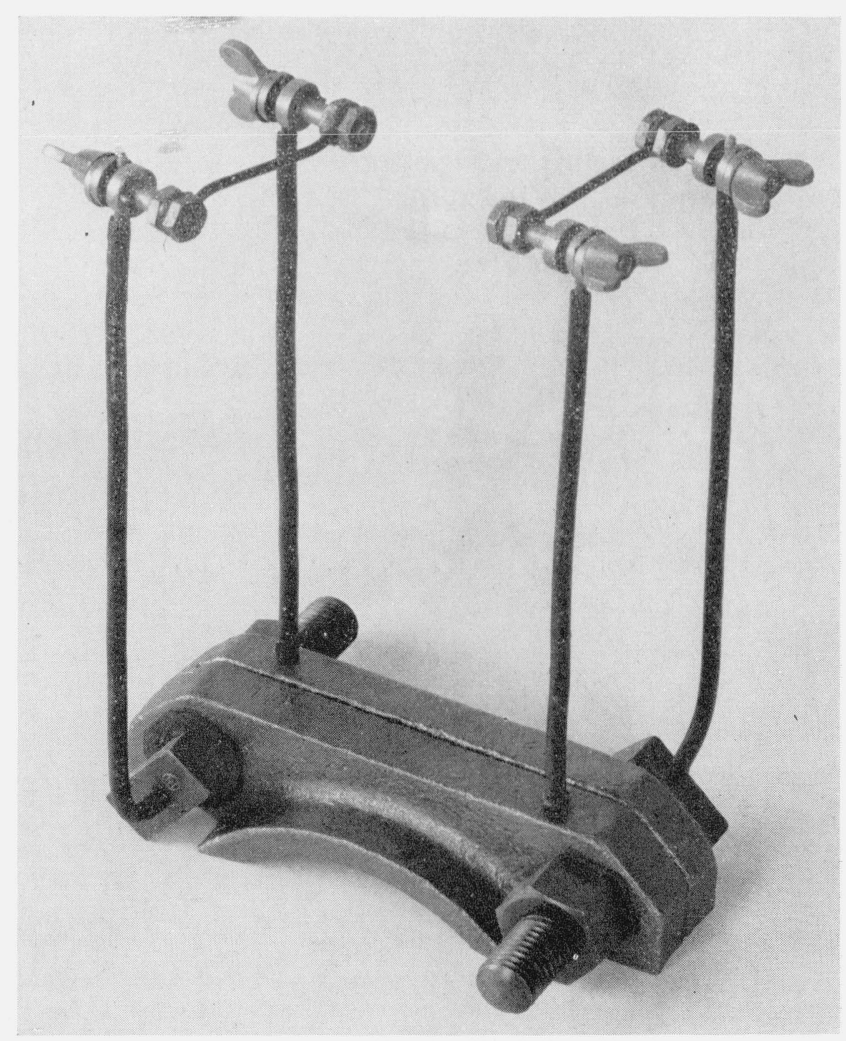

Figure 2. Couple of the type exposed to soil in the laboratory. Gland sections were cut from 4-in. cast-iron pipe glands. Bolts are 0.75 in. by 3.5 in. 
soil. The can was then filled with soil to within 4 in. from the top, allowing the insulated wires and connectors to protrude above the soil to within about $1 / 2$ in. from the top of the can.

After being weighed, the cans containing the soil and couples were placed on 1/8-in. high Bakelite supports in shallow galvanized pans (18 in. diam by 3 in. high). Water was poured into the shallow pan to a depth of about 1 in. and the soil moistening proceeded by capillarity. The water was maintained at this depth until the can and contents increased in weight by an amount equal to 30 percent of the weight of the dry soil contained therein. This final weight was maintained for the duration of the 1-year exposure period by the occasional addition of water. Except during the making of electrical measurements, the perforated covers were placed on the cans to reduce evaporation and drying of the soil.

\subsection{Electrical Measurements During Exposure}

Galvanic currents between the components of the couples and the open-circuit potentials of the components were measured biweekly during the initial 4 months of exposure, and monthly thereafter. The galvanic currents were measured with a zero resistance milliameter prior to placing the couples on opencircuit for the potential measurements. The potentials were measured with a potentiometer and a copper-copper-sulfate reference half-cell with the reference electrode being positioned on the surface of the soil directly over the couple. Two potentials were obtained on each bolt, the first being read as quickly as possible upon open-circuiting the couple, and the second after permitting the couples to stand on opencircuit for about $30 \mathrm{~min}$. Polarization effects occurring on the bolts were indicated by the change in potential between the two readings, and, as will be shown later, such polarization was also indicated by the open-circuit electromotive force between a gland section and a bolt, because the gland section polarized relatively little.

Cathodic polarization curves were obtained on each bolt before disassembling the couples for cleaning and weight-loss measurements. These data were desirable because the breaks and slopes of such curves have been shown to be related to the instantaneous rates of corrosion [4]. Before obtaining the polarization curves, each couple was left standing on open-circuit for $24 \mathrm{hr}$ to permit time for stabilization of the potentials and to observe the differences of potential between the various bolts and the glands. The polarization data were obtained with an electronic interruption measuring circuit [9]. Equal increments of current were applied at arbitrary time intervals of $3 \mathrm{~min}$.

\section{Results}

\subsection{Effect of the Galvanic Current on the Gland Sections}

Although the study was directed chiefly to the behavior of the bolts, the possible corrosive effects on the anodic member of the couple could not be dismissed. The bolts of all the couples were cathodic to the gland sections throughout the test period, even though the potentials of the cast-iron bolt $(1 \% \mathrm{Cu})$ and the plain carbon-steel bolt (table 1) were within $5 \mathrm{mv}$ of the cast-iron gland material, which could result in a potential reversal. Such reversals have been observed at the Bureau with plain ferrous bolts and the cast-iron bolts containing only 1 percent of copper. The weight losses that occurred on the gland sections are tabulated in table 2. To compare the effect of normal corrosion on a gland section with the effect of galvanic corrosion superimposed on normal corrosion, a couple was assembled in which the components were left on open-circuit throughout the exposure period. It is noteworthy that the weight loss, $95.25 \mathrm{~g}$, that occurred on the gland sections of this joint is greater than the weight losses of the gland sections removed from 50 percent of the galvanic couples, including the couple with the cast-iron bolts containing 2 percent of nickel in which the galvanic current was relatively high. These data show that local action currents on the gland sections were reduced as a result of galvanic current because, except for the couple with high-alloy cast-iron bolts, the weight losses of the gland sections were less than the sum of the weight loss attributed to galvanic current (table 2 ) and the weight loss $(95.25 \mathrm{~g})$ of the open-circuited gland sections. The reduction of the weight loss resulting from local action currents follows because of anodic polarization due to the galvanic current $[4,5]$. Top and elevation views of the gland sections

TABLE 2. Effect of the galvanic current on the corrosion of the gland sections

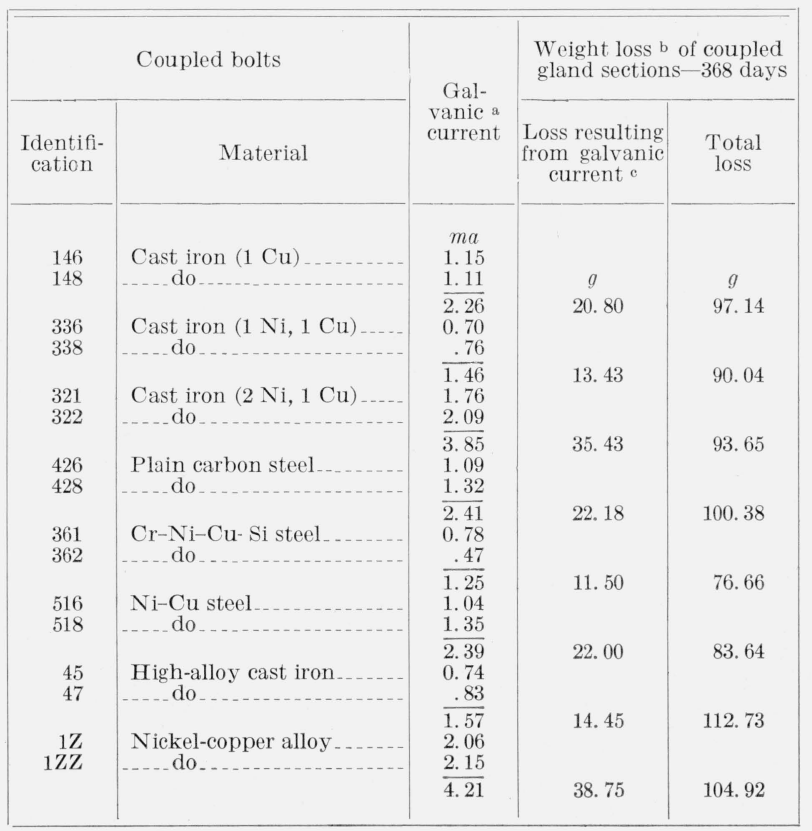

a Average value based on the area under the current versus time curve for 368 days.

b Weight loss of 2 gland sections, mechanically but not electrically coupled, was $95.25 \mathrm{~g}$. The gland area exposed to the soil was 56.6 in.2

- Calculated by Faraday's law. 

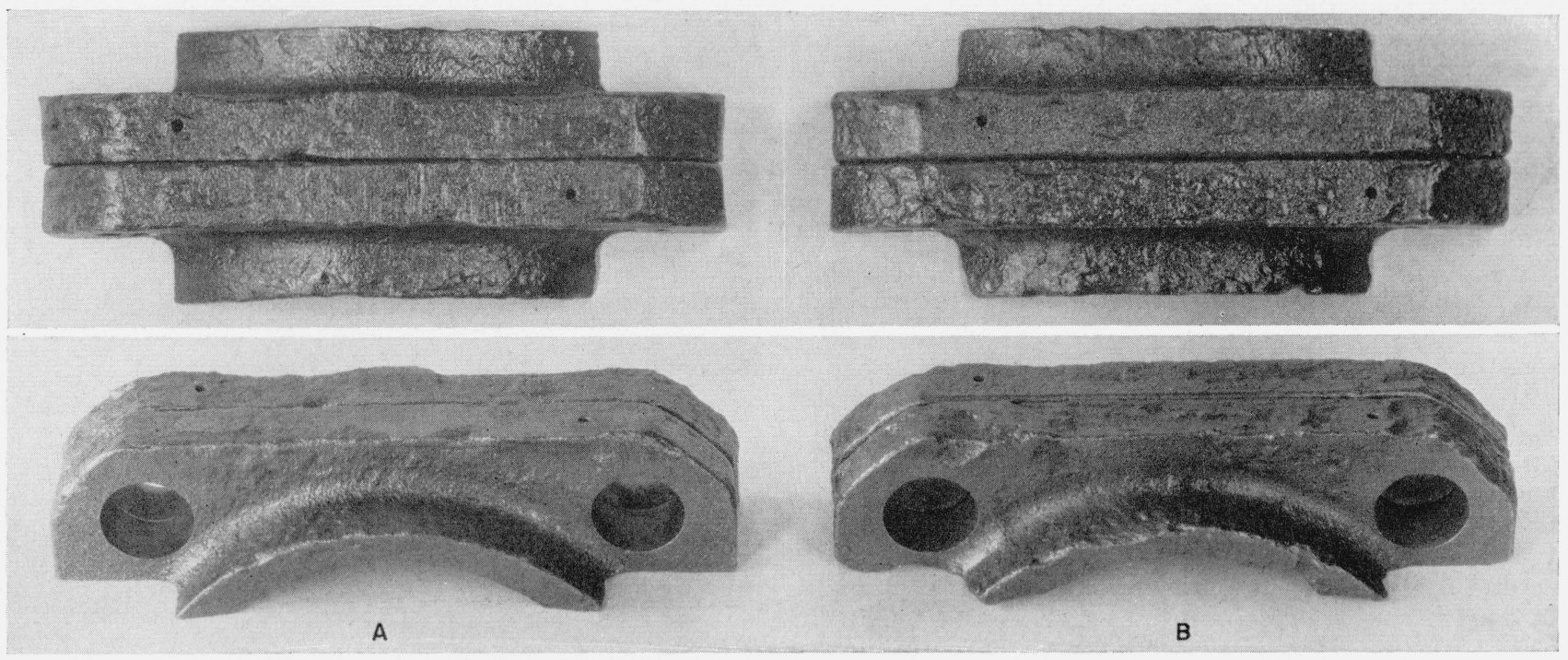

Figure 3. Top and elevation views of two sets of gland sections after soil exposure for 1 year in the laboratory. Set A was bolted but not galvanically coupled; set B was bolted and galvanically coupled.

(A) left on open-circuit and gland sections (B) galvanically coupled by bolts 321 and 322 (table 2 ) are shown in figure 3 . There is some slight evidence in the photograph B of concentrated attack, perhaps due to the galvanic current, which attack probably would be minimized on a normal underground structure, where the area relationship would be more favorable.

\subsection{Effect of the Galvanic Current on the Bolts}

Significant electrical measurements pertaining to the bolts are shown in table 3. The open-circuit electromotive force between the bolts and the gland sections after 100 days and 368 days of exposure are tabulated in columns 5 and 6 , respectively. The values shown for the 100-day exposure period were obtained after the couple had been left on opencircuit for $30 \mathrm{~min}$, and the potential differences given for the 368-day period were measured after the couple had been left on open-circuit for $24 \mathrm{hr}$. Even though the exposed gland-section to bolt-area ratio was approximately only 2 to 1 , the change of the glandsection potentials, not shown, from closed-circuit to open-circuit was relatively small, in fact, a maximum of $25 \mathrm{mv}$ in the case of the couple with the nickel-copper alloy bolts. The magnitude of the potential difference between a bolt and gland section, after open-circuiting, depended upon the amount of current that flowed when the circuit was closed. The reduction of the local action currents on the bolts, as a result of the galvanic current from

TABLE 3. Relation between weight loss and polarization of bolts

\begin{tabular}{|c|c|c|c|c|c|c|c|c|}
\hline \multicolumn{2}{|r|}{ Coupled bolts } & \multicolumn{2}{|c|}{ Galvanic current } & \multicolumn{2}{|c|}{$\begin{array}{l}\text { Open-circuit emf be- } \\
\text { tween the gland section } \\
\text { and bolt after- }\end{array}$} & \multicolumn{2}{|c|}{$\begin{array}{l}\text { Cathodic polarization } \\
\text { curve of the bolt } b\end{array}$} & \multirow{2}{*}{$\begin{array}{l}\text { Weight loss } \\
\text { of the bolt } \\
\text { after expo- } \\
\text { sure for } 368 \\
\text { days }\end{array}$} \\
\hline $\begin{array}{l}\text { Identifi- } \\
\text { cation }\end{array}$ & Material & Average a & Final & $\begin{array}{l}100 \text { days of } \\
\text { exposure }\end{array}$ & $\begin{array}{l}368 \text { days of } \\
\text { exposure }\end{array}$ & $I_{p}$ & $\begin{array}{c}\text { Slope after } \\
I_{p}\end{array}$ & \\
\hline $\begin{array}{c}146 \\
148 \\
336 \\
338 \\
321 \\
322 \\
426 \\
428 \\
361 \\
362 \\
516 \\
518 \\
45 \\
47 \\
1 Z \\
1 Z Z\end{array}$ & $\begin{array}{l}\text { Cast iron }(1 \mathrm{Cu}) \\
\text { Cast iron }(1 \mathrm{Ni}, 1 \mathrm{Cu}) \\
\text { do_ } \\
\text { Cast iron }(2 \mathrm{Ni}, 1 \mathrm{Cu}) \\
\text { Plain carbon steel } \\
\text { Cr-Ni-Cu-Si steel } \\
\text { do } \\
\text { Ni-Cu steel } \\
\text { High-alloy cast iron } \\
\text { do do } \\
\text { Nickel-copper alloy } \\
\text { do }\end{array}$ & $\begin{array}{r}m a \\
1.15 \\
1.11 \\
0.70 \\
.76 \\
1.76 \\
2.09 \\
1.09 \\
1.32 \\
0.78 \\
.47 \\
1.04 \\
1.35 \\
0.74 \\
.83 \\
2.06 \\
2.15\end{array}$ & $\begin{array}{r}m a \\
1.45 \\
1.28 \\
1.20 \\
1.10 \\
1.85 \\
1.60 \\
1.03 \\
1.27 \\
0.73 \\
.54 \\
.86 \\
1.20 \\
1.00 \\
1.28 \\
1.34 \\
1.60\end{array}$ & $\begin{array}{r}m v \\
115 \\
120 \\
30 \\
50 \\
160 \\
270 \\
55 \\
80 \\
60 \\
40 \\
140 \\
140 \\
250 \\
230 \\
380 \\
400\end{array}$ & $\begin{array}{r}m v \\
130 \\
150 \\
115 \\
115 \\
260 \\
245 \\
95 \\
120 \\
47 \\
27 \\
70 \\
130 \\
180 \\
295 \\
420 \\
445\end{array}$ & $\begin{array}{c}m a \\
0.4 \\
.4 \\
.5 \\
.25 \\
<.10 \\
.10 \\
1.20 \\
0.65 \\
.45 \\
.70 \\
.80 \\
.24 \\
\ll 0.1 \\
\ll<0.1\end{array}$ & $\begin{array}{c}v / m a \\
0.48 \\
.48 \\
.60 \\
.65 \\
.90 \\
.75 \\
.46 \\
.44 \\
.50 \\
.50 \\
.48 \\
.52 \\
1.17 \\
3.75\end{array}$ & $\begin{array}{r}g \\
5.6 \\
4.9 \\
10.3 \\
7.9 \\
3.4 \\
3.6 \\
7.5 \\
7.7 \\
6.1 \\
8.2 \\
4.8 \\
2.8 \\
0.66 \\
.57 \\
.23 \\
.15\end{array}$ \\
\hline
\end{tabular}

a Average value based on the area under the current-time curve for 368 days.

b Obtained at the end of the exposure period (see text).

- Includes weight loss of the nut. Hereafter, this is always so whenever the weight loss of the bolt is mentioned. 
the gland sections, caused the bolts to assume cathodic potentials [7]. Thus, for bolts made of materials having similar rates of corrosion, such as the 3 varieties of cast iron or the 3 kinds of steel, table 3, the larger galvanic currents generally provided for better protection of the bolts, as shown by the larger open-circuit potentials and the correspondingly lower weight losses.

It has also been shown [7] that cathodic polarization curves can be of value in predicting the degree of protection achieved as a result of previously applied external current, provided not too much time is permitted to elapse after the current is removed. In the present study, after 368 days the couples were open-circuited, and then after the lapse of $24 \mathrm{hr}$ were connected in series with an external source of direct current and cathodic polarization data obtained. Polarization curves were then drawn for each bolt. The currents, $I_{p}$, at which significant breaks in the curves were observed and also the slopes of the curves after the breaks are tabulated in table 3. Previous work [4] has shown that smaller values of $I_{p}$, or greater slopes after the break in the curve, signify lower instantaneous rates of corrosion. This relationship is generally shown by the data and reflected by the weight losses of the cast-iron bolts and also of the group of steel bolts.

The extent of reducing the corrosion on the bolts by making them cathodic to the gland sections that they coupled is shown by the data (cols. 3 and 4 , table 4) and by figures 4 and 5. These data show the beneficial effects of relatively small amounts of alloying constituents, particularly 1.5 to 2 percent of nickel. The cathodic nature of high-alloy cast iron and nickel-copper alloy resulted in almost negligible corrosion of the bolts fabricated of these materials. Although the average galvanic current (table 3) on all but two specimens is much greater than the current, $I_{p}$, (current required for cathodic protection), complete cessation of corrosion is not

TABLE 4. Comparison of weight losses of uncoupled and coupled bolts

\begin{tabular}{|c|c|c|c|c|}
\hline \multirow{2}{*}{ Bolt material } & \multicolumn{2}{|c|}{$\begin{array}{l}\text { Weight loss of bolt a } \\
\text { after } 368 \text { days of } \\
\text { exposure }\end{array}$} & \multicolumn{2}{|c|}{$\begin{array}{l}\text { Reduction in weight } \\
\text { loss of coupled bolts } \\
\text { based on control (un- } \\
\text { coupled) }\end{array}$} \\
\hline & $\begin{array}{l}\text { Control } \\
\text { uncou- } \\
\text { pled }\end{array}$ & $\begin{array}{l}\text { Coupled } \\
\text { cathodic }\end{array}$ & $\begin{array}{l}\text { Based } \\
\text { on the } \\
\text { actual } \\
\text { weight } \\
\text { loss }\end{array}$ & $\begin{array}{l}\text { Based on the b } \\
\text { calculated cor- } \\
\text { rosion rate at } \\
\text { the end of the } \\
\text { exposure } \\
\text { period }\end{array}$ \\
\hline $\begin{array}{l}\text { Cast iron }(1 \mathrm{Cu}) \\
\text { Cast iron }(1 \mathrm{Ni}, 1 \mathrm{Cu}) \\
\text { Cast iron }(2 \mathrm{Ni}, 1 \mathrm{Cu}) \\
\text { Plain carbon steel. } \\
\text { Cr-Ni-Cu-Si steel } \\
\text { Ni-Cu steel. } \\
\text { High-alloy cast iron } \\
\text { Nickel-copper alloy } \\
\text {. }\end{array}$ & $\begin{array}{c}g \\
28.5 \\
25.6 \\
33.8 \\
16.4 \\
19.7 \\
14.2 \\
8.8 \\
0.95\end{array}$ & $\begin{array}{l}\text { g } \\
5.3 \\
9.1 \\
3.5 \\
7.6 \\
7.1 \\
3.8 \\
0.61 \\
.19\end{array}$ & $\begin{array}{l}\text { Percent } \\
81.4 \\
64.4 \\
89.7 \\
53.7 \\
64.0 \\
73.2 \\
93.1 \\
80.0\end{array}$ & $\begin{array}{l}\text { Percent } \\
89.5 \\
88.7 \\
97.9 \\
56.7 \\
77.7 \\
71.9 \\
>95 \\
>95\end{array}$ \\
\hline
\end{tabular}

a Average to 2 bolts.
b Weight loss (grams) $=K t I$, where $K=2.8938 \times 10^{-4} \mathrm{~g} /$ coulomb; $t=368$ days, expressed in seconds; and $I=0.83 I_{p}$ (table 3 ) in amperes (see text).
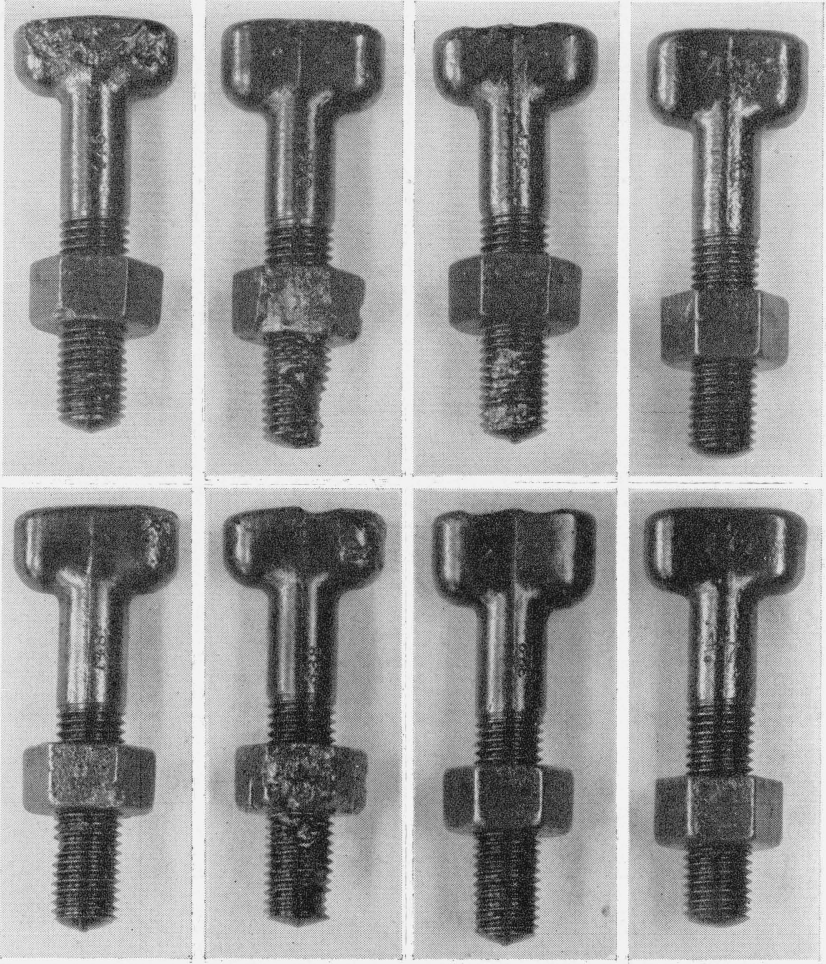

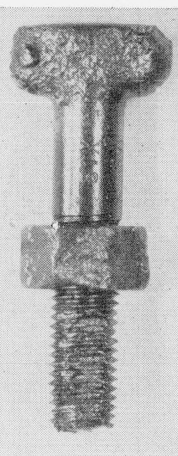

A

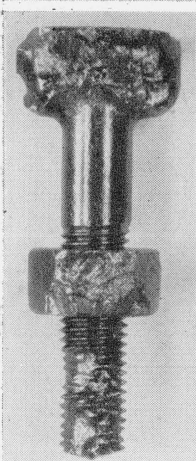

B

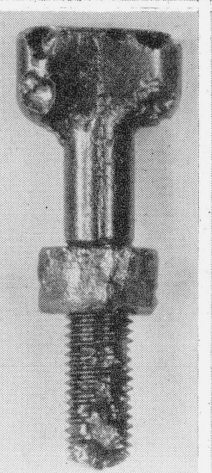

C

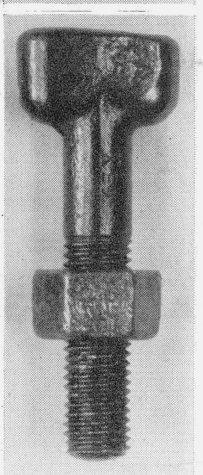

D
Figure 4. Cast-iron bolts exposed to Atlantic City soil for 1 year in the laboratory.

A, Cast iron $(1 \mathrm{Cu}) ; \mathrm{B}$, cast iron $(1 \mathrm{Ni}, 1 \mathrm{Cu})$; C, cast iron $(2 \mathrm{Ni}, 1 \mathrm{Cu})$; D, highalloy cast-iron. Bolts in the upper two rows were coupled to gland sections. Bolts in the lower row are uncoupled controls. Parts of the controls not normally in direct contact with the soil were coated with bituminous paint.

to be expected because the gland sections furnishing the current limited the potentials assumed by the bolts, preventing a drift in potential to the protective value [7].

The effect of exposure time on the corrosion rates of the various bolts is shown by the calculated data (col. 5, table 4). The calculated weight losses on which the data in column 5 are based were figured. from the breaks, $I_{p}$ in the cathodic polarization curves (table 3). The value for $I$ substituted in the Faraday equation, footnote $\mathrm{b}$, table 4 , has been previously shown to be quite reliable for plain ferrous 

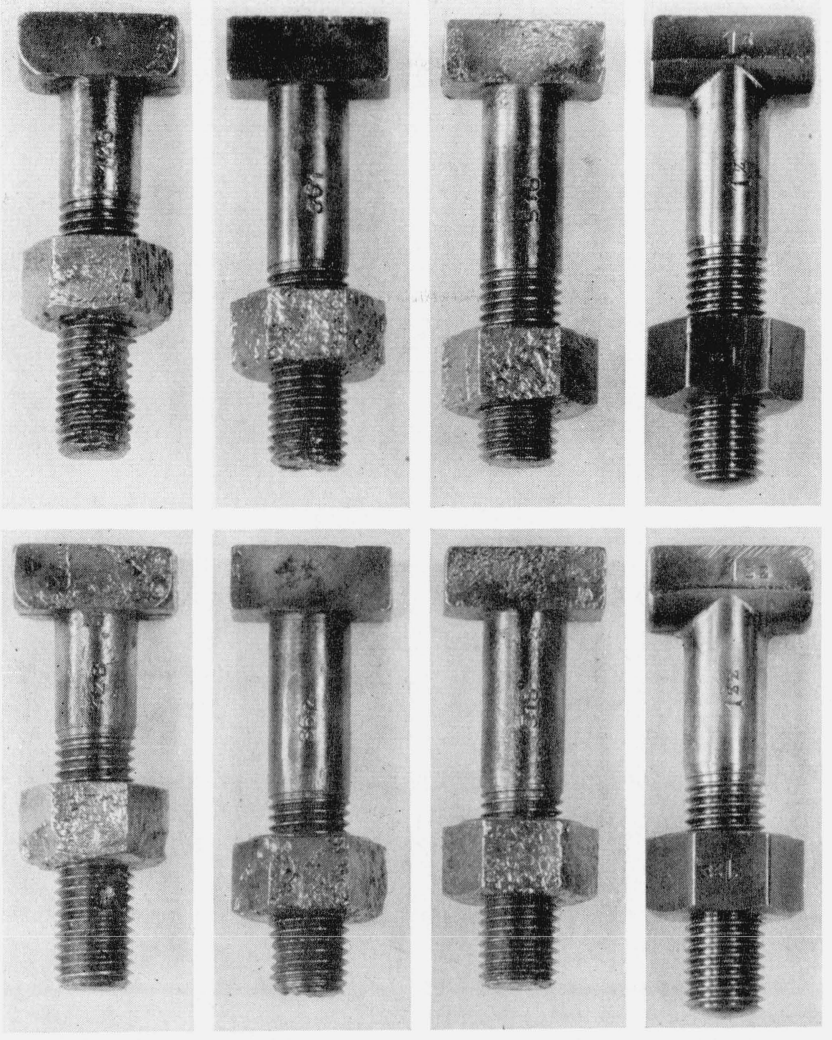

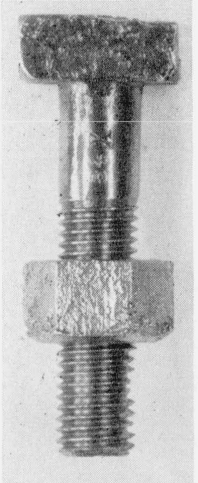

E

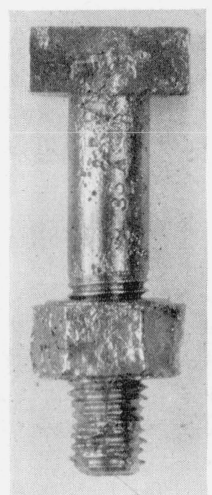

F

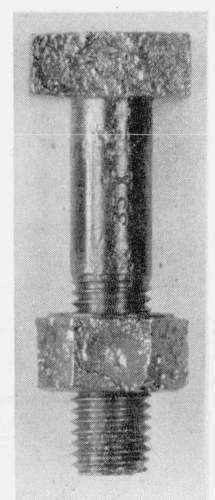

G

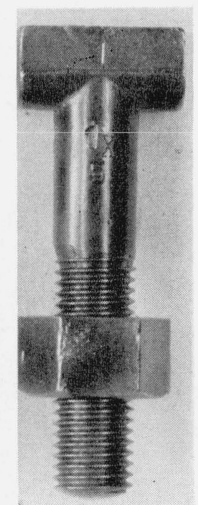

$\mathrm{H}$
Figure 5. Machined bolts exposed to Atlantic City soil for 1 year in the laboratory.

E, Plain carbon steel; F, Cr-Ni-Cu-Si steel; G, Ni-Cu steel; H, copper alloy $(70-30)$. Bolts in the upper two rows were coupled to gland sections. Bolts in the lower row are uncoupled controls. Parts of the controls not normally in direct contact with the soil were coated with bituminous paint.

materials corroding in soils [4]. A comparison of the data in columns 4 and 5 indicates, in general, that all of the bolts were corroding at a lesser rate at the conclusion of the laboratory-exposure period than previously and particularly so the cast iron $(1 \mathrm{Ni}, 1 \mathrm{Cu})$ and the Cr-Ni-Cu-Si steel bolts. Corrosion of the cast-iron bolt $(2 \mathrm{Ni}, 1 \mathrm{Cu})$ seems to have been halted.

\section{Considerations in Bolt Replacement}

\subsection{Graphitization of Cast Iron}

Wesley, Copson, and LaQue [10] have investigated experimentally the effect of graphitization on the normal corrosion of cast iron and also the galvanic action as a result of coupling graphitized and ungraphitized cast iron. These investigators found that the graphitized cast iron was cathodic, with the potential depending upon the thickness and porosity of the graphite coating. Such facts must be considered when planning the replacement of bolts, especially on underground cast-iron pipe lines.

In order to study potentials of graphitized and ungraphitized cast-iron specimens, with particular emphasis on the effect of time, measurements were made with Atlantic City soil by the method previously described. Approximately 6 in. ${ }^{2}$ each of duplicate specimens were exposed to puddled soil. The graphitized pieces were cut from the corners of a cast-iron plate that had been exposed to a corrosive soil for 13 years. The areas of iron that became exposed by cutting were covered with two coats of bituminous paint. The data obtained are shown in figure 6. As observed by Wesley, Copson, and LaQue, there is a decrease in potential difference with time between the graphitized and ungraphi-

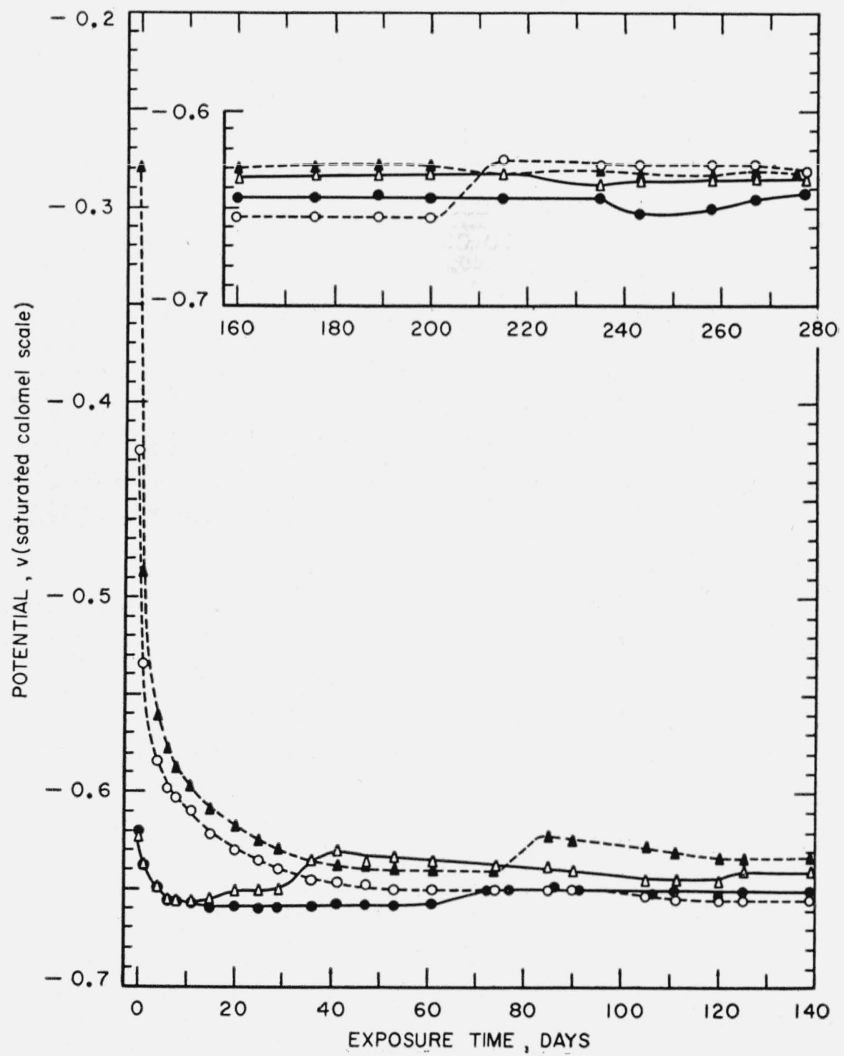

Figure 6. Potential relations between previously unexposed cast iron and graphitized cast iron in puddled soil.

. Previously unexposed; $\triangle$, previously unexposed; $\bigcirc$, graphitized, previously exposed for 13 years; $\boldsymbol{\Lambda}$, graphitized, previously exposed for 13 years. 
tized specimens. The data of figure 6 extend over a longer time period than the data obtained by these investigators. The large potential difference observed after initial exposure is of no particular significance, and for the period between 40 and 200 days it is questionable whether there is any significant potential difference. However, for the last 60 days of exposure both of the previously graphitized specimens were cathodic to the previously unexposed pieces, therefore, indicating that graphitization should be considered when replacing bolts on underground cast-iron structures.

\subsection{Potentials of Low-Alloy Steels}

Because of the tendency of cast iron and even plain steel, after long exposure, to assume potentials cathodic to similar materials previously unexposed, such as replaced bolts, made it desirable to measure the potentials of additional alloys that might be used for fabricating bolts. Potentials of 4 chromium steels and a cast iron containing 3.1 percent of nickel are tabulated in table 5. The average values are directly comparable with the average potentials recorded in table 1, being made in the same soil and under the same conditions. The average potential variation between the two specimens of each alloy was less than 2 millivolts. The effect of the amount of chromium on the potential is noteworthy. The steels containing $4.67,5.02$, and 5.76 percent of chromium are significantly cathodic to the steel containing only 2 percent of chromium and, of course, to plain steel and cast iron. The potential measurements were carried on for a considerably longer period than were most of the measurements shown in table 1. This was necessary because the potentials continued to get more cathodic as time went on, as will be noted by comparing the average and final readings (table 5). As shown by the data (tables 1 and 5 ), steel alloyed with about 5 percent of chromium is cathodic to plain steel or cast iron by at least $50 \mathrm{mv}$, and therefore might be a desirable material for use in the fabrication of bolts. The increase of nickel content in cast iron from 2 to 3.1 percent also seems to have a significant effect on the potential, as will be observed by comparing the potentials in tables 1 and 5 .

TABLE. 5. Potentials of low-alloy ferrous materials in puddled soil

\begin{tabular}{|c|c|c|c|c|c|}
\hline \multicolumn{2}{|l|}{ Material } & \multirow{2}{*}{$\begin{array}{c}\text { Expo- } \\
\text { sure } \\
\text { time }\end{array}$} & \multicolumn{3}{|c|}{$\begin{array}{c}\text { Potential, referred to saturated } \\
\text { calomel }\end{array}$} \\
\hline Composition & $\begin{array}{c}\text { Identifi- } \\
\text { cation }\end{array}$ & & Initial a & Final a & A verage $b$ \\
\hline $\begin{array}{l}\text { Steel }(2 \mathrm{Cr} \text {, with } \mathrm{Mo}) \\
\text { Steel }(4.67 \mathrm{Cr} \text {, with Mo) } \\
\text { Steel }(5.02 \mathrm{Cr}) \\
\text { Steel }(5.76 \mathrm{Cr} \text {, with } \mathrm{Mo}) \\
\text { Cast iron }(3.1 \mathrm{Ni})\end{array}$ & $\begin{array}{c}\mathrm{KK} \\
\mathrm{E} \\
\mathrm{D} \\
\mathrm{H} \\
\mathrm{N}\end{array}$ & $\begin{array}{c}\text { Days } \\
45 \\
45 \\
45 \\
45 \\
45\end{array}$ & $\begin{array}{r}v \\
-0.662 \\
-.653 \\
-.650 \\
-.653 \\
-.638\end{array}$ & $\begin{array}{c}v \\
-0.666 \\
-.629 \\
-.616 \\
-.609 \\
-.651\end{array}$ & $\begin{array}{c}v \\
-0.663 \\
-.636 \\
-.623 \\
-.623 \\
-.649\end{array}$ \\
\hline
\end{tabular}

a Average of 2 specimens.

b. Average of 19 measurements made on each pair of specimens throughout the exposure period.

\section{Effect of Exposure on the Galvanized- Iron-Iron Couple}

Long-time underground-exposure tests have shown, particularly in alkaline soils, that galvanized steel is superior to bare steel [11]. However, it cannot be concluded that galvanized bolts should be more corrosion resistant than plain-steel bolts on underground mechanical joints because in this application galvanic rather than local corrosion becomes predominant. Under such conditions the zinc coating would soon be completely corroded away and the alloy layer exposed to the soil.

While experimenting with iron-zinc-iron alloy couples in tap water, even at room temperature, Britten [12] found that the alloy layer became cathodic to the iron. Later, as a result of similar experiments, Gilbert [13] states, "the alloy remains cathodic to steel in the aerated supply water, whether hot or cold." Gilbert also found that zinc can become cathodic to iron under aerated conditions but that the alloy layer was always cathodic to zinc under similr conditions. In aerated solutions, Hoxeng [14] observed that the reversal of the zinciron couple was promoted by the addition of bicarbonates and nitrates but that chlorides and sulfates decreased the probability of reversal. Recently, Romanoff [15] measured the potentials of zinc, zinc-iron alloy layer, and steel in 12 soils by the method [7] previously described. The soils varied in $\mathrm{pH}$ from 3.1 to 8.0. The resistivities of eight of the soils were below $400 \mathrm{ohm}-\mathrm{cm}$. In none of the soils was the zinc found to be cathodic to steel, but in 11 soils the zinc-iron alloy layer was observed to be cathodic to steel on the average by $100 \mathrm{mv}$. Romanoff prepared the zinc-iron alloy layer by electrolytic stripping. This must not be confused with the surface resulting from exposure of galvanized iron to soil corrosion which surface was observed to be anodic to steel in all the soils.

The findings of the above investigators suggest the possibility that galvanized bolts underground, at least in some soil environments, may actually become cathodic to the structure of which they are a part. To investigate such a possibility under somewhat extreme conditions, a couple was prepared for exposure to a 0.2 -percent potassium chloride solution in the laboratory at room temperature. Such a solution is equivalent in resistivity (approximately $400 \mathrm{ohm}-\mathrm{cm}$ ) to a very corrosive soil. As the area ratio of structure to bolt is relatively large on underground systems, this area relation was also carried out in the laboratory experiment. The low-carbon steel that formed one element of the galvanic couple was in the shape of a disk (1/32 in. thick by $11 \mathrm{in}$. diam). The other element (hot-dipped galvanized iron) of the couple was ring-shaped having an exposed area of $1.3 \mathrm{in}^{2}$ The ring was insulated from the disk and centrally mounted about 1 in. above it. Rubber-insulated copper wires were soldered to each of the elements and the solder and exposed copper coated with bituminous paint. The couple was placed into a glass jar (11.5 in. diam by 12 in. high) 


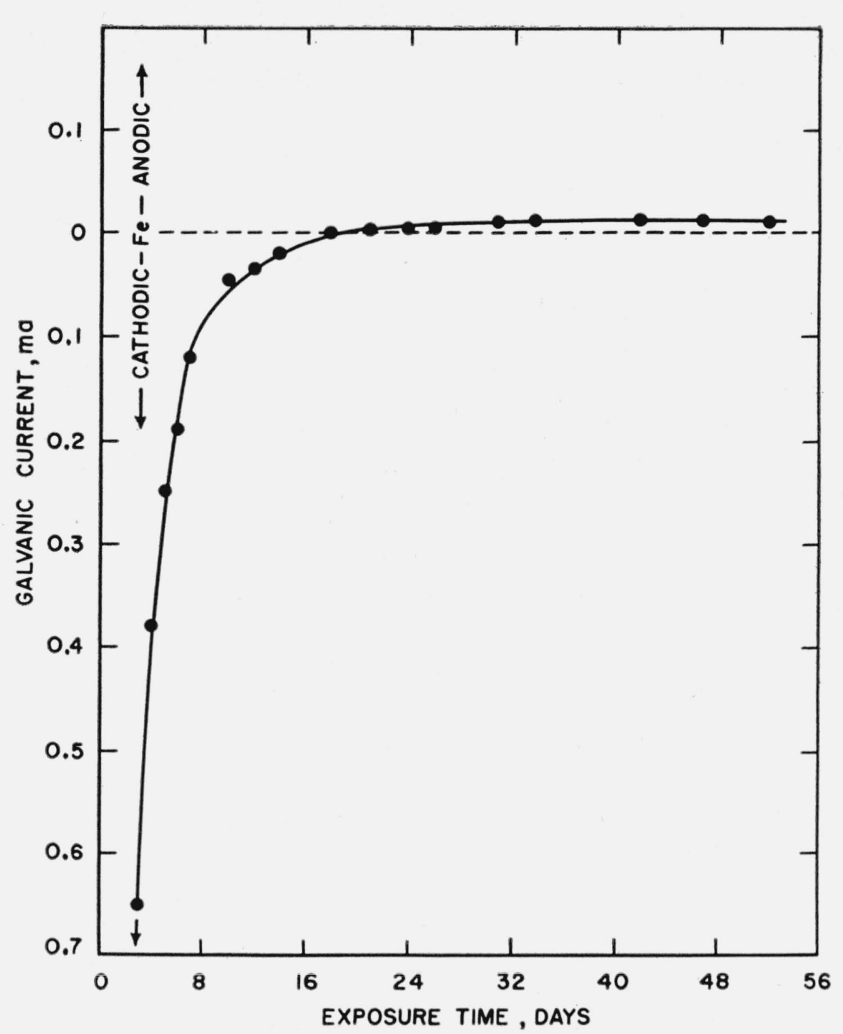

FIGURE 7. Effect of exposure time on the galvanic current of a galvanized iron-iron couple exposed to a 0.2-percent potassiumchloride solution at room temperature.

Galvanic current was initially 15 ma. After five additional months of exposure, the direction and magnitude of the galvanic current remained unchanged.

filled with the potassium-chloride solution and rested on insulators about 1 in. above the bottom of the jar, with the galvanized ring toward the top. The relation between the galvanic current, measured with a zero resistance milliameter, and time of exposure is shown in figure 7. The experiment showed that the zinc coating of itself offered no particular advantage, being removed rapidly, as indicated by the rapid decrease in current, but that the secondary effect of potential reversal must invariably result in some electrochemical protection of the exposed alloy layer. The experiment also suggests the likelihood of similar action underground, especially in soils of higher or perhaps even equivalent resistivity.

\section{Summary}

Galvanic couples consisting of cast-iron gland sections and bolts of steel and cast iron alloyed with small amounts of nickel and copper and bolts of high-alloy cast iron and nickel-copper alloy (70-30) were exposed to a corrosive soil in the laboratory for a period of 1 year. Even though galvanic current between a cathodic bolt and a structure will produce weight loss in accordance with Faraday's law, the laboratory data show that local action on the structure is reduced by the galvanic current and that the overall effect is apparently not detrimental.
This should be particularly true if the structure is relatively large and fabricated of heavy material.

It is shown that the relative reduction of weight loss of the cathodic bolts can generally be predicted by potential changes of the bolts after placing the couples on open-circuit. The relative degrees of protection produced by the galvanic currents on the various bolts after exposure for 1 year were also indicated by cathodic polarization curves.

The effect of graphitization of cast iron as a result of 13 years of field exposure on the potential is shown by comparison with the potential of previously unexposed cast iron. The importance is brought out of the length of exposure time when making potential measurements.

Potentials of steels containing chromium in varying amounts between 2 and 5.76 percent were measured in a puddled soil. Steel alloyed with 5 percent of chromium was observed to be cathodic to unalloyed ferrous material by about $50 \mathrm{mv}$, indicating that it might be a desirable bolt material especially for bolt replacement purposes.

The behavior of galvanized bolts underground, at least in some soils, is suggested by an experiment in which it was observed that a potential reversal occurred in a couple consisting of galvanized iron and low-carbon steel. The electrolyte used was a solution of $2,000 \mathrm{ppm}$ of potassium chloride in tapwater at room temperature. This chloride concentration is greater than that of many corrosive soils and considerably in excess of the amount heretofore believed sufficient to prevent a reversal.

The author gratefully acknowledges the cooperation of the United States Pipe \& Foundry Co., American Cast Iron Pipe Co., Youngstown Sheet \& Tube Co., and the Carnegie-Illinois Steel Corp. in supplying most of the materials for this study.

\section{References}

[1] M. R. Whitmore and J. Teres, Dissimilar metal couples, Ind. Eng. Chem. 31, 608 (1939).

[2] F. L. LaQue and G. L. Cox, Some observations of the potentials of metals and alloys in sea water, Proc. ASTM 40, 670 (1940).

[3] H. R. Copson, Distribution of galvanic corrosion, Trans. Electrochem. Soc. 84, 71 (1943).

[4] W. J. Schwerdtfeger and O. N. McDorman, Measurement of the corrosion rate of a metal from its polarizing characteristics, J. Electrochem. Soc. 99, 407 (1952).

[5] O. Gatty and E. C. R. Spooner, The electrode potential behavior of corroding metals in aqueous solutions, $\mathrm{p}$. 283 (Oxford University Press, London, 1938).

[6] C. K. Donoho and J. T. MacKenzie, Control of galvanic corrosion of iron, Corrosion 2, 20 (1946).

[7] W. J. Schwerdtfeger and O. N. McDorman, Potential and current requirements for the cathodic protection of steel in soils, J. Research NBS 47, 104 (1951) RP2233.

[8] Ralph Landau and C. S. Oldach, Corrosion of Binary Alloys, Trans. Electrochem. Soc. 81, 521 (1942).

[9] Robert B. Darnielle, Measurement of electrode potentials and polarization in soil-corrosion cells, J. Research NBS 25, 421 (1940) RP1336. 
[10] W. A. Wesley, H. R. Copson, and F. L. LaQue, Some consequences of graphitic corrosion of cast iron, Metals \& Alloys 7, 325 (1936).

[11] Irving A. Denison and Melvin Romanoff, Corrosion of galvanized steel in soils, J. Research NBS 49, 299 (1952) RP2366.

[12] S. C. Britton, The resistance of galvanized iron to corrosion by domestic water supplies, J. Soc. Chem. Ind. 55, $19 \mathrm{~T}$ (1936).
[13] P. T. Gilbert, The corrosion of zinc and zinc-coated steel in hot waters, Pittsburgh International Conference on Surface Reactions, p. 21 (Corrosion Publishing Co., Pittsburgh, Pa., 1948).

[14] R. B. Hoxeng, Electrochemical behavior of zinc and steel in aqueous media-Part 2, Corrosion 6, 308 (1950).

[15] Melvin Romanoff, National Bureau of Standards (unpublished).

Washington, January 8, 1954. 